\title{
Macro Invertebrates Functional Feeding Groups, Hilsenhoff Biotic Index, Percentage of Tolerant Taxa and Intolerant Taxa as Major Indices of Biological Assessment in Ephemeral Stream in Sudano-Sahelian Zone (Far-North, Cameroon)
}

\author{
D. Madomguia ${ }^{1,2}$, S.H. Zebaze Togouet ${ }^{2} *$ and A. Fomena ${ }^{2}$ \\ ${ }^{1}$ Departementt of Hydraulic and Water Management, Higher Institute of Sahel, \\ P.O. Box 46 University of Maroua, Cameroon \\ ${ }^{2}$ Laboratory of General Biology, Faculty of Science, P.O. Box 812, University of \\ Yaoundé I, Cameroon \\ *Corresponding author
}

A B S T R A C T

Keywords

Sudano-sahelian zone, Macro invertebrates, functional feeding groups, taxonomic approach.

Article Info

Accepted:

25 September 2016

Available Online:

10 October 2016
The aim of this study carried out in Mayo Tsanaga River was to determine the major indices which are more appropriate to characterize ephemeral stream in Sudano-Sahelian zone. Despite the influence of human activities in watershed physicochemical characteristics did not reveal a poor quality of water due to organic pollution. But the HBI values, the dominance of tolerant taxa to organic pollution on intolerant taxa at all sampling periods and the dominance of macroinvertebrates community by collectors-gatherers showed a site rich in organic matter, specially FPOM in suspension. The river is colonized by multivoltine species which are able to accomplish several life cycles during the short flow duration.

\section{Introduction}

Macroinvertebrate is the main group of organisms using to study the ecology of running water. They play fundamental roles in aquatic ecosystems: they are intermediate consumers and thus serve as channels by which bottom-up and top-down forces are transmitted (Wallace et al., 1999); they are excellent bioindicators and then, they are used to evaluate the effects of human wastes on the aquatic ecosystem integrity
(Mandaville, 2002, Moisan \& Pelletier, 2008).

Two general approaches are usually employed world-wide to conduct biological assessments of streams and rivers: taxonomic approach and functional approach (Cumming et al., 2005). The taxonomic approach is focused to determine the richness/diversity or biotic indices 
(Rosenberg and Resh, 1983; Hilsenhoff, 1988). The taxonomic richness and composition are usually used to quantify aquatic communities and to assess their sensibility to perturbations (Poff \& Zimmerman, 2010; Carlisle et al., 2011). The functional approach is based on easily recognized of the morphological and behavioral characteristics of the invertebrates that are related to their modes of food acquisition.

Feeding strategies are typical traits that reflect the adaptation of species and they could form part of a unified communities differing in taxonomic composition (Statzner et al., 2004). Feeding measures encompass functional feeding groups (FFGs), a classification of macroinvertebrates using morpho-behavorial mechanisms of food acquisition. Macroinvertebrates are classified based on their mechanisms for obtaining food and the particle size of food they eat (Cumming et al., 2005). Then, shredders are the invertebrates that chew Coarse Particulate Organic Matter (CPOM), composed mainly of leaves falling down from riparian vegetation (litter or live vascular plant tissue); scrapers harvest attached algae from surface of substrates; collectors feed Fine Particulate Organic Matter (FPOM): collectors-filterers collect FPOM from the water column using a variety of filters and collectors-gatherers remove FPOM from the stream bottom (in suspension); predators are those invertebrates that capture and consume live animals.

The functional composition of macroinvertebrates communities, quantified as the proportions of these different FFGs, has important implications for ecosystem functioning (Minshall et al., 1983). Ecological patterns and processes in aquatic ecosystems have been shown to vary at multiple spatial scales, between and within aquatic habitat (Meritt et al., 2002).

The aim of this study is to determine the major approach which is more appropriate to characterize aquatic ecosystems attributes in Sudano-Sahelian zone.

\section{Materials and Methods}

\section{Description of study area}

This study was carried out in Mayo Tsanaga (during 2013 and 2014), an ephemeral stream running out at south part of Maroua (fig. 1), a town situated at Sudano-Sahelian zone of Cameroon. Maroua is a town with more than 500.000 habitants situated between latitudes $10^{\circ} 26^{\prime} 41^{\prime}-11^{\circ} 00^{\prime} 13^{\prime}{ }^{\prime} \mathrm{N}$ and between longitudes 14\% $8^{\prime} 40^{\prime \prime}$ $14^{\circ} 38^{\prime} 44^{\prime}$ 'E which experiences two seasons of unequal length. During a study realized in 2013 and 2014, the dry season prolongs for about 9-10 months, from mid-October to the end of July. The short rainy season is only for about 2-3 months, from end of July to the first of October. Annual rainfall ranges from 400 to $1000 \mathrm{~mm}$ and the atmospheric temperature is situated between $15-43^{\circ} \mathrm{C}$ (L'Hôte, 1999). The studied river is composed of sandy sediments covered by a small layer of leaf litter near the vegetation of the bank. Stream bank vegetation is scarce and consists mainly of grasses (Ipomoea carnea ssp. fistulosa (Convolvulaceae) is the major grass on this vegetation). No impediment blocks the flow. The predominant microhabitats are sand, litter and vegetation. We also note the absence of shading canopy around the rivers.

The river is ephemeral and the stream duration varies between the years: 12 weeks in 2013 (from July 23 to October 8) and 7 weeks in 2014 (from August 5 to September 
17). Intense sand mining takes place there throughout the year. The width of the river is between 60 and $100 \mathrm{~m}$ or more. During permanence of water, this activity permanently changes the slope of the stream bed and for instance wet areas from one week to another and this especially when they remains only very few water in the streambed. The tides, the flow duration and the depth of water column varied closely with rainfall. Sedimentation and alteration of the banks are noticeable between the rain, and the depth of the banks rarely exceeds 50 $\mathrm{cm}$.

Mayo Tsanaga River drains specially a nonhabitant zone. Agriculture and breeding are the major human activities that occur along the stream. Nevertheless, it receives the wastes from "SODECOTON", an industry specialized in the extraction of cotton oil, and also from a slaughterhouse which dumps the contents of beef's stomach and blood into the river. Six sites were selected in Mayo Tsanaga (fig. 1).

\section{Measures of abiotic variables}

At the level of each sampling stations, eight (08) environmental variables were taken into account. Hydrological variables - maximum depth of water column during the sampling (Hwt) and water velocity - were measured every week during the flow duration. Hwt $(\mathrm{cm})$ was estimated using a graduated stick. In fact, the maximum depth of water at the time of sampling (Hwt) permits to differentiate three periods of flow duration. The first period, named "beginning-flow duration" corresponds to Hwt $\leq 50 \mathrm{~cm}$; the second period called "mid-flow duration" refers to the period of floods with Hwt $>50$ $\mathrm{cm}$, and the third period is "end-flow duration" refers to Hwt $\leq 50 \mathrm{~cm}$. Current velocity $(\mathrm{m} / \mathrm{s})$ was evaluated by timing 3 times the front of a light object (polystyrene) over a known distance along the station. Measurements of physicochemical parameters of water at the different sampling stations were done according to APHA (1998) and Rodier et al., (2009) standards at 3 moments. Thus, water temperature $\left({ }^{\circ} \mathrm{C}\right)$, $\mathrm{pH}(\mathrm{CU})$ and electric conductivity (EC; $\mu \mathrm{S} / \mathrm{cm})$ were measured in situ using WAGTECH $\mathrm{pH}$-meter for $\mathrm{pH}$ and EXTECH EC500 multiparameter for the others. Nitrates $(\mathrm{mg} / \mathrm{L})$, ammonium $(\mathrm{mg} / \mathrm{L})$ and orthophosphates $(\mathrm{mg} / \mathrm{L})$ were measured in the laboratory with UV-VIS UV RS 2500 spectrophotometer and appropriate chemical reagents. Collections of water were made in flood channel from 7 a.m. to 1 p.m. during the flow.

\section{Sampling and identification of macroinvertebrates}

Sampling of macroinvertebrates was also conducted between 7 am to $1 \mathrm{pm}$ every week during water permanence. Invertebrates were collected using a kick-net (30 x $30 \mathrm{~cm}$ side, $300 \mu \mathrm{m}$ mesh size, $30 \mathrm{~cm}$ depth) from any identified microhabitat (sand, plant, litter, dead wood, roots of plants). Macroinvertebrates are thus dislodged from the targeted habitat by dredging with the net. Some organisms with considerable size are caught by hand using pliers.

Later on, samples were transferred into a 15 $\mathrm{L}$ plastic bucket containing the water to a primary sort in order to eliminate coarse particles (plants, leaves, dead wood). Then, the samples were filtered through a plankton net (64 $\mu \mathrm{m}$ porosity), taking care to leave the sand at the bottom of the bucket. When necessary, the sand was stirred repeatedly to let the residual float benthic organisms. Thereafter, the filter contents were transferred to glass bottles of $250 \mathrm{~mL}$ and organisms were fixed in $10 \%$ formalin. In 
the laboratory, after rinsing the samples with tap water to get rid of formalin, a secondary sort is performed on the residual substrate in order to extract the remaining invertebrates. This sorting is done, firstly using naked eyes for the largest specimens, and secondly under a magnifying glass MOTIC stereomicroscope brand for smaller specimens. Organisms were manipulated in Petri dishes of $90 \mathrm{~cm}$ diameter using tongs to handle them. The fauna so concentrated were preserved in $70^{\circ}$ ethanol for further identification and enumeration.

The identification and counting of organisms were made under the MOTIC stereomicroscope. The identification keys used were, Durand and Levêque (1981), De Moor et al. (2002, 2003a, 2003b, 2007), Tachet et al. (2006) Szpila (2010) and Moisan (2010)

\section{Data analyses}

Taxonomic indices and functional indices were used for analyses. Taxonomic indices include taxonomic richness, taxonomic abundance, diversity indices (H', J), Hilsenhoff's Biotic Index (HBI), EPT/ Chironomidae ratio, percentage of intolerant taxa (\%IT) and percentage of tolerant taxa (\%TT) of organic pollution. They were calculated to estimate the degree of perturbation doing the presence of organic matter on the site of study. The formulas were followed:

$$
\begin{gathered}
\text { HвI }=\sum \frac{x_{i} t_{i}}{n} \\
\% I T=\frac{\text { abondunce of taxa with } F T V<4}{\text { total abondunce }} * 100 \\
\% T T=\frac{\text { abondunce of taxa with FTV }>6}{\text { total abondunce }} * 100
\end{gathered}
$$

$\mathrm{X}_{\mathrm{i}}=$ total number of individuals belonging to taxon $\mathrm{i} ; \mathrm{t}_{\mathrm{i}}=$ tolerance of taxon $\mathrm{i} ; \mathrm{n}=$ total number of individuals in the sample, FTV = Family Tolerance Value to organic pollution.

Functional indices include the calculation of the density/abundance of any functional feeding group recognized in our samples and the calculation of some FFG ratios, especially autotrophic to heterotrophic index $(\mathrm{P} / \mathrm{R})$. The formula was:

$P / R=\frac{s c r}{s h r+c-f+c-g}$

Scr, shr, c-g and c-f represent the abundances of scrapers, shredders, collectors-gatherers and collectors-filterers respectively.

The interpretation of $\mathrm{P} / \mathrm{R}$ index was inspired by the work of Cummins et al. (2005). These authors indicate that an ecosystem is autotrophic when $\mathrm{P} / \mathrm{R}>0.75$.

\section{Results and Discussion}

\section{Hydrological variables}

The maximum depth of water and current velocity at the moment of sampling are presented at figure 2 . Hwt varied from 0 to $105 \mathrm{~cm}$ in 2013 and from 0 to $80 \mathrm{~cm}$ in 2014. We are remark that the day of beginning of the flow permanence varies from one year to another. It not possible to predict it; it depends both on the quantity of rain and the duration of the dry season. The duration of our three periods of flow permanence are as followed:

- 2-3 weeks (end of July - mid August) for beginning-flow permanence where Hwt $\leq$ $50 \mathrm{~cm}$; 
- 3-4 weeks (mid-August to midSeptember) for mid-flow permanence with Hwt > $50 \mathrm{~cm}$;

- 2-3 weeks (mid-September to midOctober) for end-flow permanence with Hwt $\leq 50 \mathrm{~cm}$.

The water flow velocity fluctuated between 0 and $1.52 \mathrm{~m} / \mathrm{s}$ in 2013 and between 0 and $1.32 \mathrm{~m} / \mathrm{s}$ in 2014 . It varies highly from one week to another; however, its profile is similar in all stations (especially in 2014).

\section{Physicochemical variables}

The means and ranges values of measured physicochemical factors are shown in table 1. Water temperature lies between $26.7^{\circ} \mathrm{C}$ (A) and $37.0^{\circ} \mathrm{C}(\mathrm{C})$. The mean indicates that water temperature increases from "beginning-flow duration" to "end-flow duration". The $\mathrm{pH}$ values varied between $7.12 \mathrm{CU}$ (A) and $8.74 \mathrm{CU}$ (B). Electric conductivity (EC) ranged from $39.42 \mu \mathrm{S} / \mathrm{cm}$ (C) to $1332 \mu \mathrm{S} / \mathrm{cm}$ (B). Lowest value of nitrates $\left(0.001 \mathrm{mg} / \mathrm{L} \mathrm{NO}_{3}{ }^{-}\right)$was recorded at "beginning-flow duration" whereas the highest value $\left(1.512 \mathrm{mg} / \mathrm{L} \mathrm{NO}_{3}{ }^{-}\right)$registered at "mid-flow duration". Ammonium ranged to $0.001 \mathrm{mg} / \mathrm{L} \mathrm{NH}_{4}{ }^{+}$(C) to $1.850 \mathrm{mg} / \mathrm{L}$ $\mathrm{NH}_{4}{ }^{+}$(A). Phosphates varied from 0.058 $\mathrm{mg} / \mathrm{L} \mathrm{PO}_{4}{ }^{3-}$ (B) to $1.832 \mathrm{mg} / \mathrm{L} \mathrm{PO}_{4}{ }^{3-}$ (A). The mean values of electric conductivity, nitrates and ammonium indicate that the water of the study River was weekly mineralized.

A Hierarchical Ascending Classification (HAC) performed to cluster sampling period according to their physicochemical water quality status distinguished 2 groups of periods. Group I made up of "beginningflow duration" and "end-flow duration" corresponds to the period of low water where the maximum depth of water at the time of sampling equal to or lower than 50 $\mathrm{cm}$. Group II is constituted only by "midflow duration", a period corresponding to high water (Hwt > $50 \mathrm{~cm})$. A Principle Component Analysis (PCA) was elaborated with physicochemical parameters (fig. 3) (F1 axis and $\mathrm{F} 2$ axis represented $100 \%$ ). Axis F1 (58.96 \%) determined "end-flow duration" and temperature, ammonium and phosphates whose max values are obtained on this period. F2 axis (41.04 \%) is determined by "beginning-flow duration" and "mid-flow duration" and by the variables that indicate water mineralization degree (nitrates, ammonium, $\mathrm{pH}$, electric conductivity). However, ammonium was more abundant at "beginning flow duration" and others were more abundant at "mid-flow duration"

\section{Taxonomic indices and degree of pollution by organic matter}

A total of 24935 individuals (15210 individuals in 2013 and 9725 individuals in 2014) distributed in 57 taxa (1 Oligochaeta, 2 Crustaceans, 4 Molluscs and 50 Insects) were collected during 3 sampling periods. The "end-flow duration" was more diversified and abundant (55 taxa, 11589 individuals) than "mid-flow duration" (53 taxa, 7166 individuals) and "beginning-flow duration" (48 taxa, 6180 individuals). 5 taxa concentrated $70.42 \%$ of total abundance (Ephemeroptera Baetidae: $32.97 \%$; Heteroptera Corixidae: $16.87 \%$; Diptera Chironomidae: $\quad 9.58 \%$; Odonata Coenagrionidae: $6.69 \%$ and Oligochaeta: $4.31 \%)$. They are not significative difference between the 3 sampling periods (Kruskall-Wallis test: $\mathrm{p}=0.101 ; \alpha=0.05$ ).

Shannon-Wiener index values are lower than 1.5 bits at each period during the water permanence while taxa evenness was equal to 0.02 at the same time (tab. 2). The higher 
value of EPT/Chironomidae ratio (5.52) was recorded at "mid-flow duration" when the lower value (1.17) was recorded at "endflow duration". HBI values varied between 4.849 ("beginning-flow duration") and 5.866 ("end-flow duration"). Tolerant taxa were dominant than intolerant taxa at each sampling period (fig. 4).

\section{Functional feeding groups}

Five functional feeding groups (FFGs) were recognized in this study. These include collectors-gatherers (c-g), predators (prd), collectors-filterers (c-f), scrapers (scr) and shredders (shr). Globally, collectorsgatherers were the most abundant FFGs during the study period, followed by predators and scrapers (fig. 5). The densities of c-g, prd and c-f growth during the flow duration while the density of scr decrease during the same time. The autotrophy to heterotrophic index $\mathrm{P} / \mathrm{R}$ was lower than 0.75 at all period of sampling (tab. 3) and shows that the study area is strongly heterotrophic.

Permanent hydrological changes were mentioned in Mayo Tsanaga ephemeral stream. These hydrological changes create an instability that reverberates on physicochemical composition of water and on the macroinvertebrates community composition. Indeed, hydrology is a fundamental factor influencing ecosystem dynamics, life-history strategies and diversity patterns in running-water habitats (Schriever et al., 2014). Macroinvertebrates was more abundant in 2013, the rainy year with long flow permanence than 2014. It shows the positive influence of rainfall on the one hand and the flow duration on the other hand on the development of aquatic invertebrates in Sudano-Sahelian zone. Schriever et al. (2014) notify that taxonomic richness, functional richness and taxonomic abundance increased with increased flow permanence in desert stream and decreased when drying events are frequent. Flow duration is a strong driver of macroinvertebrates community composition, but additional abiotic factors also have a significant effect on faunal assemblages (Mazzacano and Hoffman Black, 2008).

The waters of the river have remained warm throughout the study although it was carried out in the rainy season. The permanent reheating of the water can be attributed to the absence of canopy coverage which can reduce the incidence of solar rays on water. The presence or absence of a shading canopy has also been seen as an important driver of invertebrate community structure in stream of differing flow duration (Dieterich, 1992; Dieterich et al., 1997), because the level of sunlight (insolation) regulates the amount and type of food base present (Mazzacano and Hoffman Black, 2008). Organisms colonizing waters of Mayo Tsanaga River are therefore eurythermal and eurytopic. Foothill zones and low mountains are characterized by species with wide ecological valence that colonize every habitat types independently of substrate and current velocity (Haouchine, 2011). Environmental parameters informing about the degree of mineralization of water generally show that the waters of the studied site are weakly mineralized (Nisbet and Verneaux, 1970) despite the various organic pollution dumped in the watershed and the river. But all the studies conducted in perennial streams sweeping areas with high human pressure under tropical and equatorial climate show strong mineralization of water done by the organic hazards (Foto menbohan, 2012; Onana Fils, 2015; Ebang Menye, 2014; Tchakonte, 2015). This difference is due to the phenomenon of drift of pollutants following the high flows that knows the Mayo Tsanaga River after rains. 
However, this low water mineralization could not guarantee its good quality which can promote their use as drinking water. The higher electrical conductivity values recorded in "mid-water permanence" (1332 $\mu \mathrm{S} / \mathrm{cm}$ ) are related to the fact that the samples were taken at a time when the effluent of "SODECOTON" arrived in the river. The literature suggested that the $\mathrm{pH}$ range favorable to the development of many aquatic organisms ranges between 6.29 and 7.07 CU (Anonymous 1999). However, the $\mathrm{pH}$ of the water obtained in this study varied from 7.12 and 8.14 CU. This rise in $\mathrm{pH}$ can be attributed to the calcareous and clayey soils of the "Diamaré" plain where the studied stretch of the Mayo Tsanaga River flows. Rodier et al., (2009) states that the $\mathrm{pH}$ of natural waters is linked to the nature of the crossed land, limestone helps in raising the $\mathrm{pH}$. However, the higher value of this parameter obtained in "midpermanence" of water can also be due to the contributions of "SODECOTON".

As we predicted, HAC clearly distinguishes two water regimes and 3 periods in Mayo Tsanaga. PCA defines phenomena and physicochemical parameters dominating on each period. After the long dry season, reduction of organic substances present in the aquatic environment in the "beginningflow duration" produced mainly $\mathrm{NH}_{4}{ }^{+}$. Thereafter, the turbulences created by large variations in flow in "mid-flow duration" favour the increase of oxygenation of the water thanks to the exchanges at the airwater interface. This increase of water oxygenation favours mineralization of organic matter, consequently the dominance of physicochemical parameters that indicate the degree of mineralization of water $\left(\mathrm{NO}_{3}{ }^{-}\right.$ and Electrical Conductivity). Moreover, the water streaming bring the calcareous and clayey substances erased from the ground, which increases the water $\mathrm{pH}$. Finally, at the "end of water permanence", the rains stop and the gradual lowering of the depth of the remained water accentuate the influence of the sun and the water temperature increases. In addition, the stability occurs and causes the deposition of large quantities of detritus which the remineralization by the temperature increases the rate of phosphates. In fact, at the "end of water permanence", human activities are conducted in the water bed discharge hazards, including human and animal excrements. Trianfyllou et al., (2000) state that large quantities of detritus remineralized by high temperatures increase the rate of many salts like phosphates salts. The positive correlation between temperature and $\mathrm{PO}_{4}{ }^{3-}$ ions $(\mathrm{n}=0,465 ; \alpha=$ $5 \%$ ) confirms that the temperature catalyzing metabolic reactions promoting the release of orthophosphate ions in the water.

Globally, the physicochemical variables do not reveal poor water quality of the study site. Likewise, the taxonomic richness and abundance of Benthic Macroinvertebrates do not indicate a site impacted by human activities. Indeed, the community of aquatic invertebrates collected in the rhithron of Mayo Tsanaga account 24935 individuals distributed within 57 families. A similarly study in five perennial rivers watershed Mfoundi, highly influenced by human activities, revealed a cumulative taxonomic richness of 29 families (Nangmo 2004; Nyamsi Tchatcho 2004; Kiampi Choffo 2004; Ebang Menye, 2004). Our results are similar to those of Foto Menbohan (2010 and 2013) obtained in the Nga stream located in the same ecoregion of Mfoundi but in the suburban surface. These authors have described an aquatic invertebrates community consisting of 59 families in 2010 and 74 families in 2013. However, only 1455 individuals and 2553 individuals were counted during the respective years. Our 
results indicate that ephemeral streams of the Sudano-Sahelian zone are colonized by multivoltine species able to accomplish several life cycles during the short flow duration. According to Tachet et al., (2006), a high proportion of multivoltine species is an indication of a higher instability in the environment. This instability is caused here by the permanent hydrological changes that occur in the river. According to several authors (Dieterich, 1992; Ohio EPA, 2002; Bonada et al., 2007; Mazzacano and Hoffman Black, 2008), ephemeral streams are generally considered to be either completely lacking in invertebrates than perennial streams. Our results show that the higher temperature in tropical area permits the development of several organisms that can complete their life cycles rapidly before the stream dries. Comparative studies of invertebrate community composition in perennial and intermittent streams frequently reveals a high degree of overlap (Williams, 1987; Delucchi \& Peckarsky, 1989; Boulton \& Lake, 1992; Dieterich, 1992; Feminella, 1996; Banks, 2005; Beche et al., 2006), with the majority of taxa being common to both types of streams.

The EPT/Chironomidae ratio values were higher in each period (>1) and show good health and low organic pollution of the study site as the physicochemical parameters, the taxonomic richness and abundance.

Table.1 Mean and ranges values of environmental parameters evaluated at each period of the flow duration during the study period

\begin{tabular}{|c|c|c|c|c|}
\hline & A & B & C \\
\hline \multirow[t]{2}{*}{$\mathrm{T}\left({ }^{\circ} \mathrm{C}\right)$} & Mean & 29,7 & 31,6 & 34,0 \\
\hline & Range & $26,7-32,6$ & $30,0-34,2$ & $31,2-37,0$ \\
\hline \multirow[t]{2}{*}{$\mathrm{pH}(\mathrm{CU})$} & Mean & 7,15 & 7,94 & 7,92 \\
\hline & Range & $7,12-7,18$ & $7,62-8,74$ & $7,74-8,45$ \\
\hline \multirow[t]{2}{*}{$\mathrm{EC}(\mu \mathrm{S} / \mathrm{cm})$} & Mean & 130,0 & 327,0 & 101,4 \\
\hline & Range & $92,13-211,85$ & $97,6-1332,0$ & $39,45-204,05$ \\
\hline \multirow[t]{2}{*}{ Nitrates $\left(\mathrm{mg} / \mathrm{L} \mathrm{NO}_{3}^{-}\right)$} & Mean & 0,088 & 0,562 & 0,087 \\
\hline & Range & $0,001-0,434$ & $0-1,512$ & $0,020-0,287$ \\
\hline \multirow[t]{2}{*}{ Ammonium (mg/L NH$\left.{ }^{+}\right)$} & Mean & 0,541 & 0,458 & 0,164 \\
\hline & Range & $0,30-1,850$ & $0,260-1,100$ & $0,001-0,564$ \\
\hline \multirow[t]{2}{*}{ Phosphates (mg/L $\left.\mathrm{PO}_{4}{ }^{3-}\right)$} & Mean & 0,536 & 0,186 & 1,284 \\
\hline & Range & $0,141-1,832$ & $0,058-0,358$ & $0,302-1,810$ \\
\hline
\end{tabular}

Table.2 Values of H', J, EPT/Chironomidae, HBI, \%TT and \%IT of each sampling period

\begin{tabular}{lrrr}
\hline & A & B & C \\
\hline H' & 0.759 & 0.997 & 1.123 \\
J & 0.02 & 0.02 & 0.02 \\
EPT/Chironomidae & 2,67 & 5,52 & 1,17 \\
HBI & 4,85 & 4,86 & 5,87 \\
\% TT & 2,33 & 4 & 17,28 \\
\%IT & 0,94 & 1,82 & 1,32 \\
\hline
\end{tabular}


Fig.1 Map of the study site showing the sampling stations

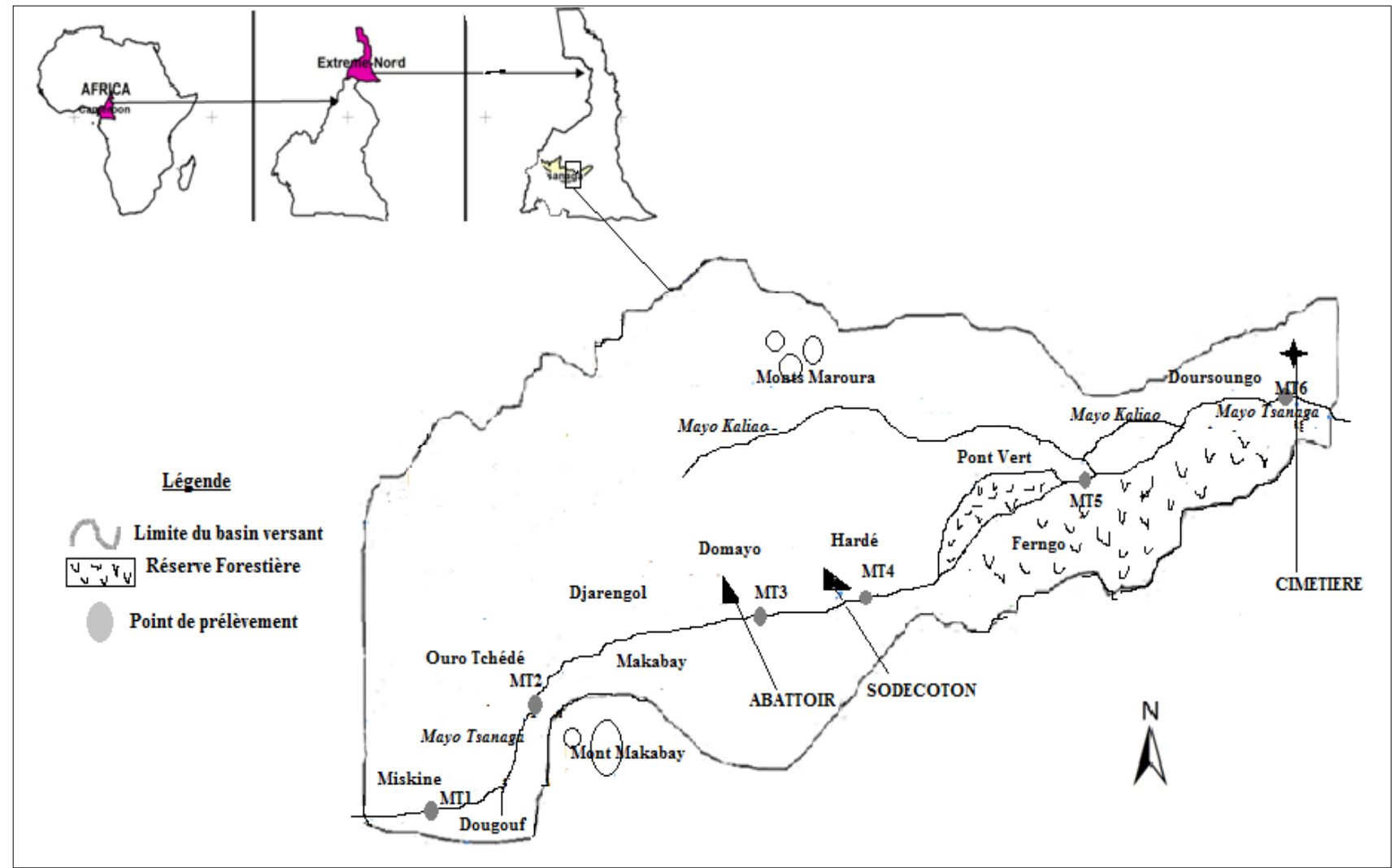

Fig.2 The variation of the maximum depth of water (Hwt) and the current velocity (V) at the moment of sampling during the study period.

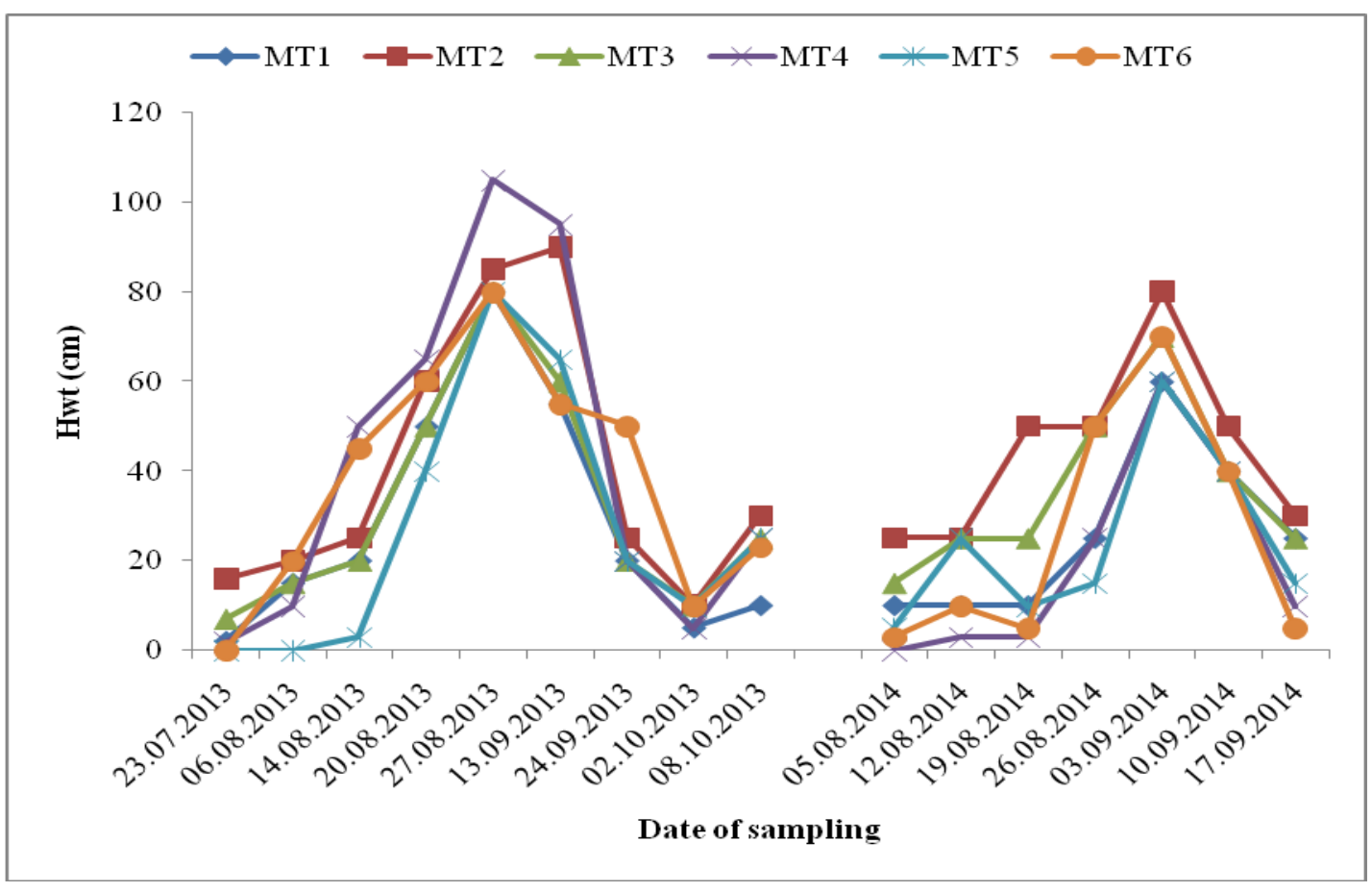




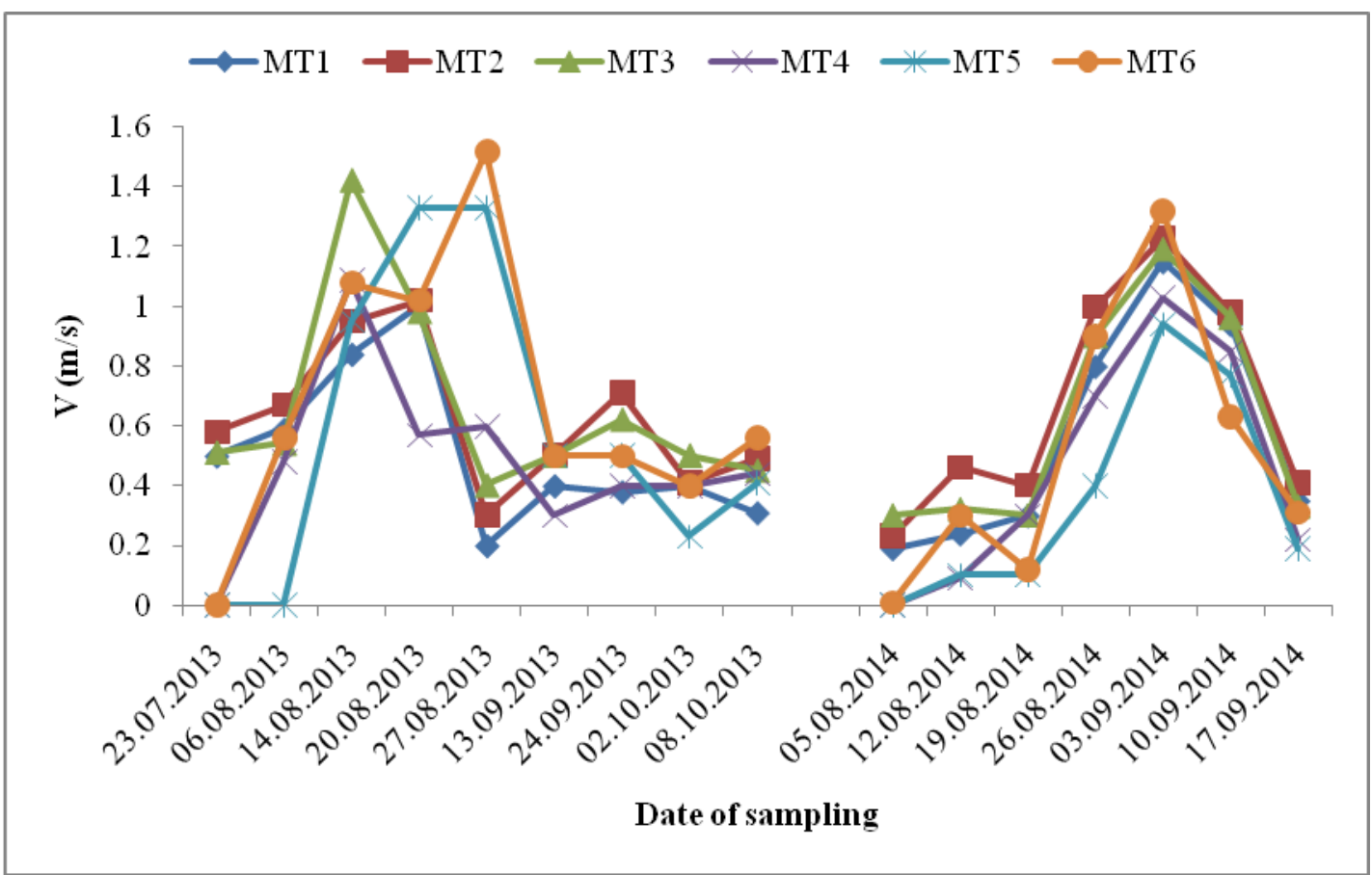

Fig.3 Projections of the water permanence period and the physicochemical variables of water samples collected on the plane of the first two axes of the PCA (axis 1 horizontal and axis 2 vertical).

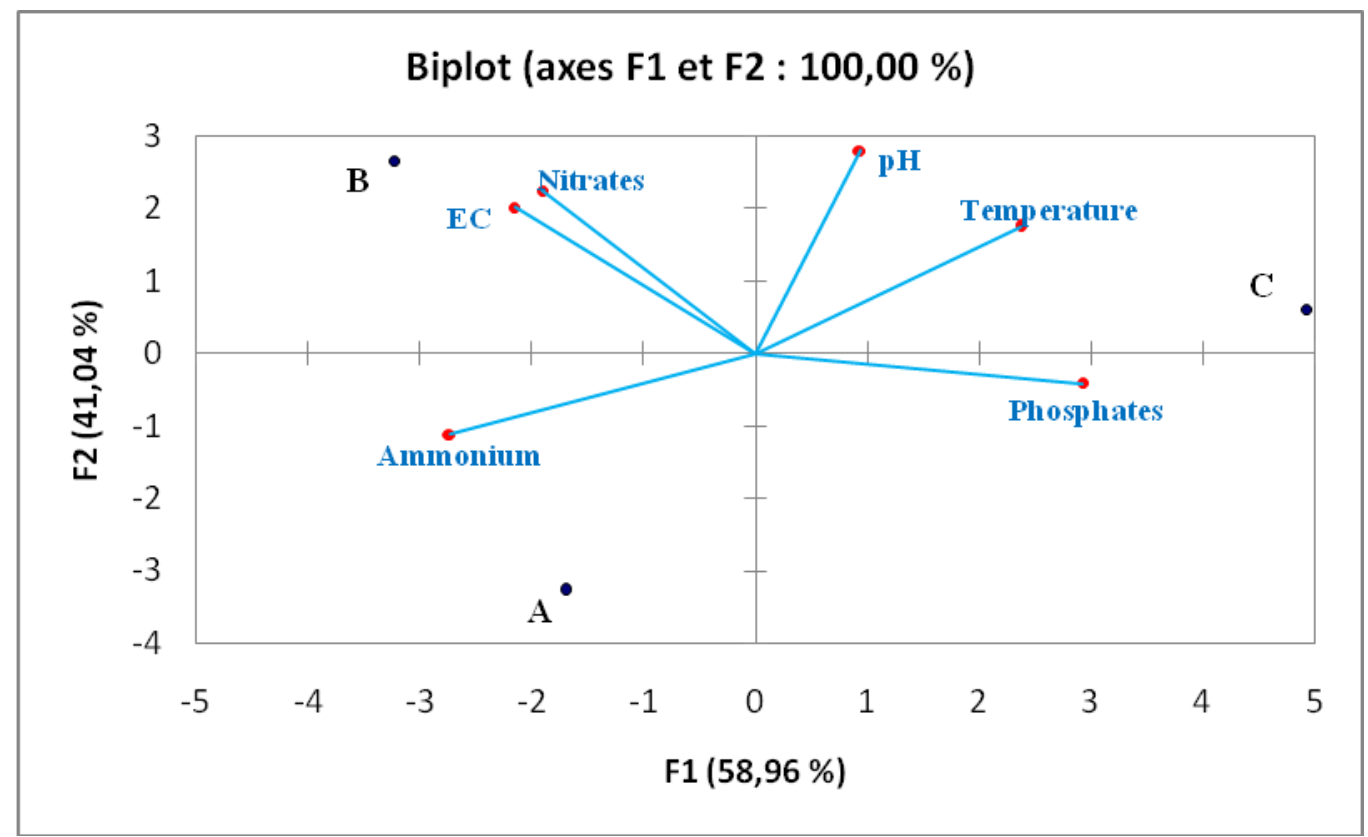


Fig.4 Percentages of tolerant taxa and intolerant taxa at each sampling period

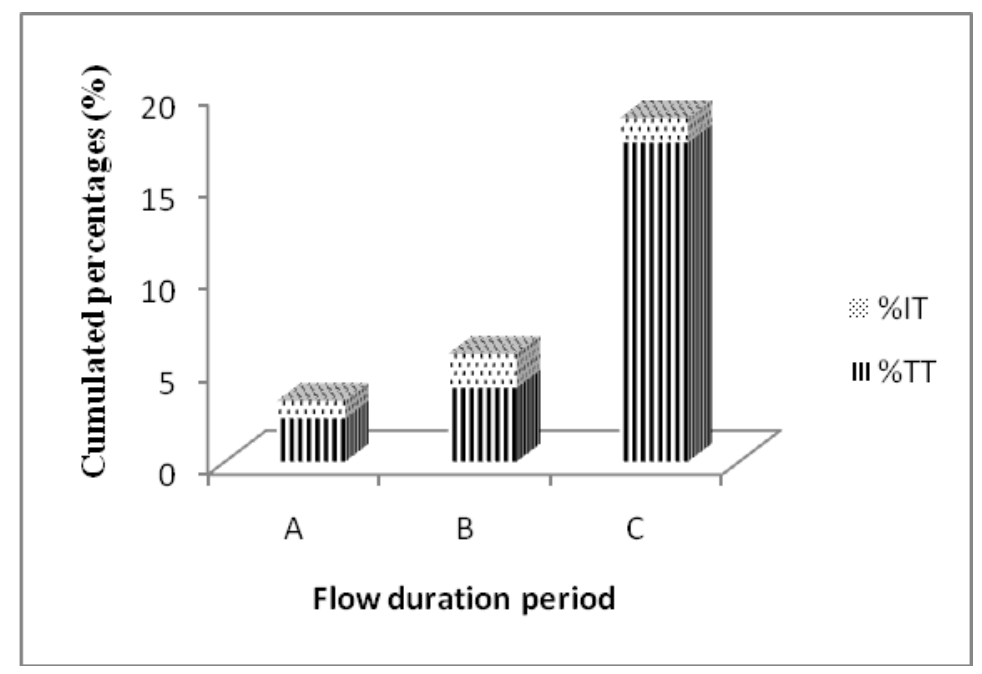

Fig.5 Functional feeding groups collected in study site

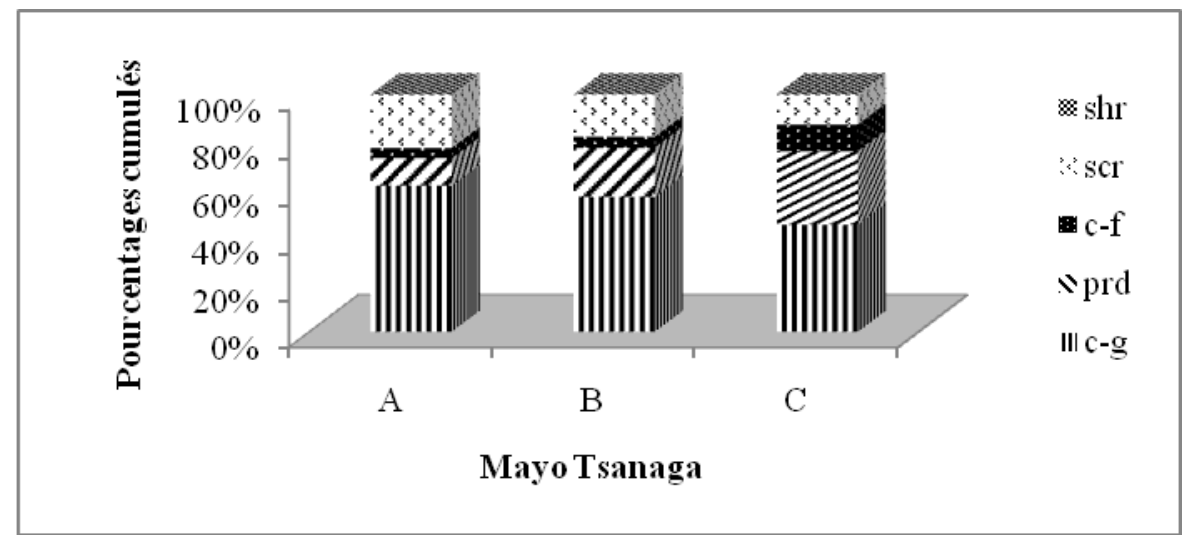

However, HBI values show water from good to fair quality corresponding to some to fairly significant organic pollution (Mandaville, 2002). This is reinforced by the dominance of tolerant taxa of intolerant taxa on organic pollution as well as very low values of the Shannon-Wiever index that showing this site is an azoic to very highly polluted environment (Simbouras and Zenetos, 2002). Moreover, the dominance of collector-gatherers indicates a site rich in organic matter because their proliferation in a milieu is related to the presence of Fine Particles of Organic Matter (FPOM) in suspension in water which serve as food (Palmer et al., 1993). Also, the $\mathrm{P} / \mathrm{R}$ index revealed that the site is strongly heterotrophic (Cumming et al., 2005). This being, we can say that indicators based on physicochemical composition of water and taxonomy are not sufficient to define a diagnosis of temporary water. Any study in this register must incorporate Hilsenhoff's Biotic Index (HBI), percentage of Intolerant and Tolerant Taxa (\%TT, \%IT) and traits based on feeding strategies. Functional approach may be more appropriate and is certainly more rapid (Cummins et al., 2005). 
The community of Benthic Macroinvertebrates of Mayo Tsanaga River is made up of collectors (filterers and gatherers), predators, scrapers and shredders. The dominance of collectors revealed that the FPOM are the major food resources, the part in suspension being more abundant. The progressive increase of the density of the collectors-gatherers and predators show the progressive enrichment of the environment by organic substances. However, the high abundance of predators is primarily related to the great diversity of Diptera such as chironomid which they feed (Diomandé, 2001).

In conclusion, this study revealed a difference between the functioning of perennial stream running in forestry zone and ephemeral stream running in SudanoSahelian zone. The major traits to describe ephemeral stream are HBI, percentage of tolerant and intolerant taxa of organic pollution and functional feeding groups.

\section{References}

Ajonina, A.S. 2014. Impacts of climate variability and anthropogenic factors on composition, distribution and abundance of macroinvertebrates along the shores of River Ndongo, Buea south west region Cameroon. Int. J. Curr. Microbiol. Sci., ISSN: 23197706, Vol. 3, $N^{\circ}$ 9, 454-468.

American Public Health Association. 1998. Standard method for examination of water and wastewater. 20th Ed., Washington DC.

Anonymous. 1999. Système d'évaluation de la qualité de l'eau des cours d'eau : Grilles de seuils par usage et fonction. 1(B): 23p.

Beche, L.A., McElravy, E.P. and Resh, V.H. 2006. Long-term seasonal variation in the biological traits of benthic- macroinvertebrates in two Mediterranean climate streams in California, U.S.A. Freshwater Biol., 51: 56-75.

Bonada, N., Rieradevall, M., and Prat, N. 2007. Macroinvertebrate community structure and biological traits related to flow permanence in a Mediterranean river network. Hydrobiologia., 589: 91-106.

Boulton, A.J. and Lake, P.S. 1992b. Benthic organic matter and detritivorous macroinvertebrates in two intermittent streams in south-east Australia. Hydrobiologia 241: 107-118.

Carlisle, D.M., Wolock, D.M. and Meador, M.R. 2011. Alteration of stream flow magnitudes and potential ecological consequences: a multiregional assessment. Frontiers in Ecol. Environ., 9: 264-270.

Cummins, K.W., R.W. Merritt and Andra P.C.N. 2005. The use of invertebrate functional group to characterize ecosystem attributes in selected streams and rivers in south Brazil. studies on Neotropical Fauna and Environment, 40(1): 69-89.

De Moor I.J., J.A. Day and De Moor F.C 2003a. Guides to the Freshwater Invertebrates of Southern Africa Volume 8: Insecta II. Hemiptera, Megaloptera, Neuroptera, Trichoptera \& Lepidoptera. Prepared for the Water Research Commission, WRC Report No. TT 214/03, 219p.

De Moor I.J., J.A. Day and De Moor F.C. 2007. Guides for Freshwater Invertebrates of Southern Africa. Vol. 10: Coleopteran. Prepared for the Water Research Commission, WRC Report No. TT 207/03., 275p.

De Moor, I.J., J.A Day, De Moor, F.C. 2002. Guides to the Freshwater Invertebrates of Southern Africa Volume 9: Diptera. Prepared for the 
Water Research Commission, WRC Report No. TT 214/03, 210p.

De Moor, I.J., J.A. Day and De Moor F.C 2003b. Guides to the Freshwater Invertebrates of Southern Africa Volume 7: Insecta I. Epheroptera, Odonata, Plecoptera. Prepared for the Water Research Commission, WRC Report No. TT 214/03, 301p.

Delucchi, C.M. and Peckarsky, B.L. 1989. Life history patterns of insects in an intermittent and a permanent stream. $J$. North American Benthol. Soc., 8(4): 308-321.

Dieterich, M. 1992. Insect community composition and physico-chemical processes in summer dry streams of western Oregon. Ph. D. thesis, Oregon State University, Corvallis OR, 191p.

Dieterich, M. and Anderson, N.H. 1995. Life cycles and food habits of mayflies and stoneflies from temporary streams in western Oregon. Freshwater Biol., 34: 47-60.

Diomandé, D. 2001. Macrofaune benthique et stratégies alimentaires de Synodontys batiani (Daget, 1948) et S. schall (Bloch \& Schneider, 1801) (Bassins Bia et Agnébi; Côte d'Ivoire) Thèse $\mathrm{Ph}$, Université d'AboboAdjamè $243 \mathrm{p}$.

Durand, J.R et Lévêque, C. 1981. Flore et faune aquatiques de l'Afrique sahelosoudanienne (Tome II). Paris, France: ORSTOM, 483 pp.

Ebang Menye, D. 2004. Evaluation de la charge polluante organique et ses effets écologiques sur l'Ewoué, affluent de la rive gauche de la rivière Mfoundi à Yaoundé. Mémoire de DEA, Faculté des Sciences, Université de Yaoundé I au Cameroun ; 64p.

Ebang Menye, D., S.H.Zébazé Togouet, S. Foto Menbohan, N. Kemka, M. Nola, C. Boutin, V.F. Nguetsop, D. Moussa et Njiné, T. 2014. Bio-écologie des diatomées épilithiques de la rivière Mfoundi (Yaoundé, Cameroun) : diversité, distribution spatiale et influence des pollutions organiques. Revue des sciences de l'eau / J. Water Sci., vol. 25, $n^{\circ}$ 3, 203-218.

Feminella, J.W. 1996. Comparison of benthic macroinvertebrates assemblages in small streams along a gradient of flow permanence. J. North American Benthol. Soc., 15: 651-669.

Foto Menbohan, S. 2012. Recherches écologiques sur le réseau hydrographique du Mfoundi (Yaoundé) : Essai de biotypologie. Thèse de Doctorat d'Etat en Biologie des Organismes Animaux, Université de Yaoundé I. Cameroun, $175 \mathrm{p}+$ annexes.

Foto Menbohan, S., S. Tchakonte, G.A. Ajeagah, S.H. Zebaze Togouet, C.F Bilong Bilong. et Njine T. 2013. Water quality assessment using benthic macroinvertebrates in a periurban stream (Cameroon). Int. J. Biotechnol., 2(5): 91-104.

Foto Menbohan, S., S.H. Zebaze Togouet, N.L. Nyamsi Tchatcho et Njiné T. 2010. Macroinvertébrés benthiques du cours d'eau nga: Essai de caractérisation d'un référentiel par des analyses biologiques. European $J$. Scientific Res., 43(1): 96-106.

Haouchine, S. 2011. Recherches sur la faunistique et l'écologie des macroinvertébrés des cours d'eau de Kabylie. Mémoire de Magister, Université Mouloud Mammeri de Tizi ouzou, $157 \mathrm{p}$.

Hilsenhoff, W.L. 1988. Rapid field assessment of organic pollution with a family-level biotic index. J. N. Am. Benthol. Soc., 7(1): 65-68.

Kiampi Choffo, C. 2004. Ampleur de la pollution du Mingoa par les eaux usées domestiques, et réponse des 
organismes du milieu. Mémoire de DEA, Faculté des Sciences, Université de Yaoundé I au Cameroun ; 58p.

L'hôte, Y. 1999. Climatologie in Atlas de la province Extrême Nord Cameroun, Planche 2. République du Cameroun, Ministère de la Recherche Scientifique et de la Technologie/Institut national de cartographie, $32 \mathrm{p}$.

Mandaville, S.M. 2002. Benthic Macroinvertebrates in FreshwatersTaxa Tolerance Values, Metrics, and Protocols. Soil \& Water Conservation Society of Metro Halifax (Project H1), $128 \mathrm{p}$.

Mazzacano, C. and Hoffman Black, S. 2008. Aquatic Using Aquatic Macroinvertebrates as Indicators of Stream Flow Duration. The Xerces Society for Invertebrate Conservation, Portland OR, 33p.

Merritt, R.W., K.W. Cummins, M.B. Berg, J.A. Novak, M.J. Higgins, K.J. Wessel and Lessard, J.L. 2002. Development and application of a macroinvertebrate functional-group approach in the bioassessment of remnant river oxbows in southwest Florida. J. North American Benthol. Soc., 21(2): 290 310.

Moisan, J. 2010. Guide d'identification des principaux macroinvertébrés benthiques d'eau douce du Québec Surveillance volontaire des cours d'eau peu profonds. Direction du suivi de l'état de l'environnement, Ministère du Développement Durable, de l'Environnement et des Parcs, 89p.

Moisan, J., et Pelletier, L. 2008. Guide de surveillance biologique basée sur les macroinvertébrés benthiques d'eau douce du Québec - cours d'eau peu profonds à substrat grossier. Direction de suivi de l'état de l'environnement, ministère du développement durable, de l'environnement et des parcs, 86p.
Nangmo, J.B. 2004. Evaluation de la Qualité des eaux de l'Ekozoa par utilisation des composantes physicochimiques et biologiques du milieu. Mémoire de DEA, Faculté des Sciences, Université de Yaoundé I au Cameroun, 47p.

Nyamsi Tchatcho, N.L. 2004. Effets des rejets d'une usine de traitement de la cellulose sur la qualité des eaux du Ntsomo : Etude biologique et hydrologique $d u$ cours d'eau. Mémoire de DEA, Faculté des Sciences, Université de Yaoundé I au

Ohio EPA. 2002. Field Evaluation Manual for Ohio's Primary Headwater Streams. Ohio Environmental Protection Agency, Division of Surface Water, Columbus OH, 66pp.

Onana, F.M., S.H. Zebaze Togouet, B.S. Dassié Djomo, S.C. Nna, N. Mvondo and Ngassam P. 2015. Impact de l'effluent du Complexe Chimique Camerounais (CCC) sur la structure du peuplement de macroinvertébrés benthiques d'un cours d'eau tropical urbain (Douala, Cameroun). European J. Scientific Res., volume 121 (3), pp.298-309.

Palmer, C., J. O'Keeffe, A. Palmer, T. Dunne and Radloff S. 1993. Macroinvertebrate functional feeding groups in the middle and lower reaches of the Buffalo River Eastern Cape, South Africa. I. Dietary variability. Freshwater Biol., 29: 441453.

Poff, N.L. and Zimmerman, J.K.H. 2010. Ecological responses to altered flow regimes: a literature review to inform the science and management of environmental flows. Freshwater Biol., 55: 194-205.

Rodier, J.B. Legube, N. Marlet et Brunet R. 2009. L'analyse de l'eau. 9e édition, DUNOD, Paris, 1579p. 
Rosenberg, D.M. and Resh, V.H. (eds.) 1993. Freshwater Biomonitoring and Benthic Macroinvertebrates. Chapman $\&$ Hall, New York., 488pp.

Schriever, T.A., T. Bogan, M. Boersma, K. S. Cañedo-Argüelles, M. Jaeger, K.L. Olden, Lytle, D.A. 2015. Hydrology shapes taxonomic and functional structure of desert stream invertebrate communities. Freshwater Sci., 34(2): 399-409.

Simboura, N. and Zenetos, A. 2002. Benthic indicators to use in Ecological Quality classification of Mediterranean soft bottom marine ecosystems, including a new Biotic Index. Mediterranean Marine Sci., Vol. 3/2, 77-111.

Statzner, B., S. Dolédec and Hugueny, B. Biological trait composition of European stream invertebrate communities: assessing the effects of various trait filter types. Ecography, 27: 470-488.

Szpila, K. 2010. Key for identification of European and Mediterranean blowflies (Diptera, Calliphoridae) of forensic importance Third instars. Nicolaus Copernicus University Institute of Ecology and Environmental Protection, Department of Animal Ecology, 14p.

Tachet, H., P. Richoux, M. Bournaud et Usseglio-Polatera, P. 2006. Invertébrés d'eau douce : Systématique, biologie et écologie.
CNRS édition, Paris. 588p.

Tchakonté S., Ajeagah G., Diomandé D., Camara A.I., Konan K.M., Ngassam P. 2014. Impact of anthropogenic activities on water quality and Freshwater Shrimps diversity and distribution in five rivers in Douala, Cameroon. J. Biodiversity and Environ. Sci., (JBES) ISSN: 22206663, Vol. 4, No. 2, p. 183-194.

Tchakonté, S., G. A Ajeagah, A. I. Camara, D. Diomandé, N.L. Nyamsi Tchatcho and Ngassam, P. 2015. Impact of urbanization on aquatic insect assemblages in the coastal zone of Cameroon: the use of biotraits and indicator taxa to assess environmental pollution. Hydrobiologia, Volume 749, 23p.

Triantafyllou, G., G. Petihakis, C. Dounas, D. Koutsoubas, C. Arvanitidis and Eleftheriou, A. 2000. Temporal variations in benthic communities and their response to physicochemical forcing: a numerical approach. ICES J. Marine Sci., 57: 1507-1516.

Wallace, J.B., S.L. Eggert, J.L. Meyer and Webster, JR. 1999. Effects of resource limitation on a detrital-based ecosystem. Ecol. Monographs, 69: 409-442.

Williams, D.D. 1987. The ecology of temporary waters. Timber Press, Portland OR, 205 pp.

\section{How to cite this article:}

Madomguia, D., S.H. Zebaze Togouet and Fomena, A. 2016. Macro Invertebrates Functional Feeding Groups, Hilsenhoff Biotic Index, Percentage of Tolerant Taxa and Intolerant Taxa as Major Indices of Biological Assessment in Ephemeral Stream in Sudano-Sahelian Zone (FarNorth, Cameroon). Int.J.Curr.Microbiol.App.Sci. 5(10): 792-806. doi: http://dx.doi.org/10.20546/ijcmas.2016.510.086 